\title{
A Theoretical Basis for Exploration for Native Copper in Northern Wisconsin
}

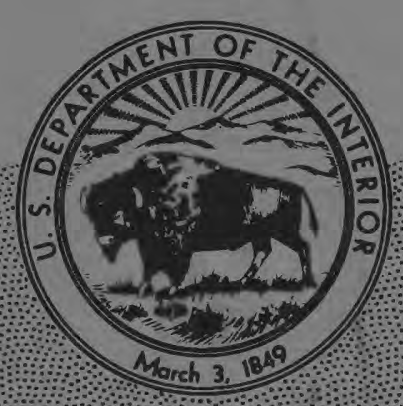




\section{A Theoretical Basis for Exploration for Native Copper in Northern Wisconsin}

By Walter S. White

GEOLOGICAL SURVEY CIRCULAR 769

Certain geologic characteristics of the

Michigan copper district can provide

exploration guides for northern

Wisconsin 
United States Department of tho Interior CECIL D. ANDRUS, Secretary

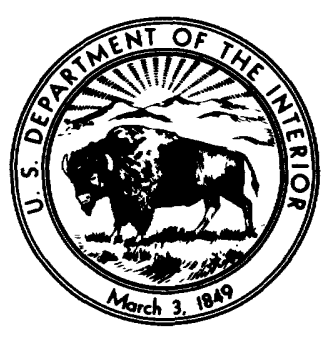

\section{Goological Survoy}

V. E. McKelvey, Director

Library of Congress catalog - card No. 78-600001 


\section{CONTENTS}

\begin{tabular}{|c|c|c|c|}
\hline & $a$ & & \\
\hline & 1 & Regional structure of the Keweenawan lavas in & \\
\hline tion ..-..-.--- & 1 & & \\
\hline & 2 & Hypothetical model of a basin of lava accum & \\
\hline c features common to younger lavas of & & & \\
\hline 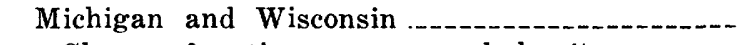 & 4 & Areas favorable for copper in hypothetical lava & \\
\hline ite -.---.--- & 4 & basins & \\
\hline ............ & 4 & Hypothetical basin A & \\
\hline$-\infty$ & 6 & (19ned & \\
\hline aleoh & 6 & & \\
\hline$m-\ldots$ & 7 & s rock & \\
\hline & 7 & nypothetic & \\
\hline & 7 & Hypothetical basin $B$ & \\
\hline cture of the Keween & & Portage Lake Volcanics..... & \\
\hline & 10 & Conclusion & \\
\hline General state & 10 & Metamorphic grade & \\
\hline $\begin{array}{l}\text { Kinds of infor } \\
\text { subdivision }\end{array}$ & & $\begin{array}{l}\text { Stratigraphy } \\
\text { Structure }\end{array}$ & \\
\hline Data available for Wiscon & & References - - - - - & \\
\hline
\end{tabular}

\section{ILLUSTRATIONS}

FIGURE 1. Generalized geologic map of Keweenawan rocks, northwestern Wis-

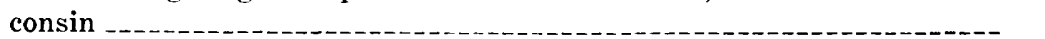

2. Diagram showing stratigraphic distribution of critical metamorphic minerals, Portage Lake Volcanics, Eagle Harbor section _........ 5

3. Diagram showing hypothetical plan of a Keweenawan flood-basalt flow 8

4. Generalized model of a Keweenawan lava basin _._. 10

5. Generalized geologic map of northwestern Wisconsin showing hypothetical basins of lava accumulation 


\title{
A Theoretical Basis for Exploration for Native Copper in Northern Wisconsin
}

\author{
By Walter S. White
}

\begin{abstract}
Exploration for native copper in the Keweenawan lavas of northern Wisconsin has been concentrated in areas of relatively shallow overburden that have sparse to numerous outcrops. Lack of success of this exploration suggests that if large deposits, comparable to those of northern Michigan, are present, they are more likely to be found in one or more of the large tracts that have few, if any, exposures, away from the "copper ranges."

A hydrologic model that may explain the mineralization of the classic native-copper district of Michigan could be helpful in suggesting that certain covered tracts are more favorable than others, and in narrowing the targets for physical exploration within these tracts. This model involves updip migration of a hydrothermal fluid of metamorphic origin, formed when ground water contained in the interstices of lava flows and conglomerate beds was carried to geat depth along the axis of the Lake Superior syncline. The largest reservoirs of such buried ground water would be expected in the peripheral rather than central parts of the basins in which the lavas originally accumulated because the ratio of porous fragmental flow tops and conglomerate beds to massive basalt should increase towards the margins of a basin. Thus, the areas most promising for copper deposits should be those updip from places where the trough of the later formed Lake Superior syncline crosses the marginal parts of a lava basin.
\end{abstract}

In Michigan, such migrating solutions deposited native copper in greatest abundance close to the boundary between epidote and pumpellyite metamorphic zones of Jolly (1974). To be most favorable, therefore, a potential target area should contain rocks of this metamorphic grade.

In order to locate areas favorable for native-copper deposits according to the hydrologic model described above, we must determine the outlines of basins of lava accumulation. This requires reasonably detailed stratigraphic information over a much larger area than that of individual tracts without outcrops. The requisite data can be obtained by conventional geologic mapping in areas that have exposures, and stratigraphic boundaries can then be interpolated or extrapolated across covered tracts with the help of ground and airborne magnetometer surveys, and possibly paleomagnetic correlations. Data from areas having ex- posures can also be used, in Wisconsin, to delimit fairly closely the covered tracts that might contain rocks of favorable metamorphic grade.

\section{INTRODUCTION}

Exploration for native copper in the Keweenawan lavas of northwestern Wisconsin has, for 130 years, been sporadically encouraged by small surface or near-surface showings. A special incentive for this exploration was the success, in Michigan, of mines in similar rocks. Exploration in Wisconsin has not been similarly rewarded. The most promising concentrations found there are tiny, even by comparison with deposits that were unsuccessfully exploited in Michigan. Butler and Burbank (1929, p. 67-98) listed nearly 100 Michigan mining companies that paid no dividends despite recorded production ranging from a few tons to as much as 12,000 tons $(11,000$ metric tons) of metallic copper. In contrast, none of the prospects in Wisconsin has any recorded production, though small amounts of copper were presumably recovered where mill tests were made.

This unpromising record is consistent with, but does not confirm, the proposition that no significant native-copper deposits are present in the Keweenawan lavas of northwestern Wisconsin. In Michigan, all the major deposits and almost all the minor deposits were found at grass roots ; many, perhaps most, from evidence of pitting by prehistoric Indians. Virtually all are in areas where outcrops are relatively common, and bedrock is probably covered by less than $6 \mathrm{~m}$ (20 feet) of surficial material over a significant fraction of any given square mile. In such terrain, the chance of finding copper stains in outcrop or soil is obviously far greater than in areas that have deep overburden and few outcrops; perhaps just as im- 
portant, the relatively shallow overburden has made it economical to further investigate such stains by trenching. Most of the deposits were found by this procedure.

In Wisconsin, essentially all the copper prospects have the same kind of setting as the deposits in Michigan - they are in areas of relatively shallow overburden characterized by rare to numerous bedrock outcrops. A comparison of the districts that contain the main prospects (see Grant, 1901, figs. 7-9, 13) with areas of similar size and exposure in the Michigan copper district suggests the following: if there had been significant copper deposits in the prospected areas, one or more of the deposits found by prospectors should have been comparable in size and grade to the many in Michigan that have produced at least a few tons of metallic copper. Therefore, if there are large deposits in Wisconsin, they probably are not in the areas that have numerous outcrops and copper prospects-the "copper ranges" of Grant (1901). If major deposits do exist, they are, conversely, most likely to be in areas that have few, if any, exposures, away from the "copper ranges."

Within the area immediately underlain by Keweenawan lavas in northwestern Wisconsin are large tracts in which no outcrops were noted in the course of detailed traverses by the Wisconsin Geological and Natural History Survey (see distribution of symbols for outcrops on Dutton and Bradley, 1970, sheet 1). Large parts of many townships and a few whole townships appear to have no exposures (Dutton, 1972), and such well records as exist for these areas reveal deep overburden. The largest of these outcrop-free tracts are probably the best places in which to concentrate exploration efforts. Because the actual search for copper deposits must ultimately involve expensive drilling in greater or less degree, criteria that can help narrow target areas beforehand are, as always, highly desirable. The purpose of this paper is to present some criteria suggested by characteristics of the Michigan copper district and its regional setting.

The discussion here of elements of the geology of northwestern Wisconsin is based entirely on published or open-file material and not on any original field observations by me in Wisconsin. It would be presumptious of me to pretend that, as far as Wisconsin is concerned, the ideas presented here are any more than speculations, which is my reason for setting them out in a Circular rather than in a more formal publication. Field observations may prove or disprove some elements of these speculations, and thus the speculations suggest geologic and geophysical investigations that would be useful.

\section{GEOLOGIC SETTING}

The rocks likely to contain native-copper deposits are, as in Michigan, a thick series of mafic lava flows and a few interlayered felsitic conglomerate or sandstone beds. In Michigan, these copper-bearing rocks have been called the Portage Lake Volcanics (formerly "Portage Lake Lava Series"). In westernmost Michigan, the Portage Lake Volcanics overlie an older, more metamorphosed series of lavas, the Powder Mill Group (Hubbard, 1975), which is not known to contain significant concentrations of copper. As shown in figure 1, the Portage Lake Volcanics seem to pinch out near Mellen, Wis., the pinchout marking the western end of the basin in which they accumulated (White, 1966a, p. E18 and fig. 7 ; 1972).

In northwestern Wisconsin, west of Mellen, there also appears to be at least a twofold division of the mafic lava flows (fig. 1). A belt of conglomerate extending southwest from Davis Hill (secs. 2 and 11, T. 44 N., R. 6 W.; lat. $46^{\circ} 19^{\prime} \mathrm{N}$., long. $91^{\circ} 5^{\prime} \mathrm{W}$.; near east end of unit labeled conglomerate of Davis Hill on fig. 1) was regarded by Aldrich (1929) as equivalent to the Copper Harbor Conglomerate (fig. 1), which overlies the Portage Lake Volcanics in Michigan and east of Mellen in Wisconsin. Aldrich thought that the volcanics to the south of the conglomerate belt of Davis Hill were the same as those to the north, and that the presence of two belts was due to repetition on a fault (Lake Owen fault). Hubbard's $(1975$, p. 529) recognition of rocks of his Powder Mill Group in the southern belt indicates that the conglomerate belt of Davis Hill separates an older group of lavas from a younger, and may mark an unconformity between the two. The "Lake Owen fault" of Aldrich may exist, but it is not necessary to explain the geologic relationships. 


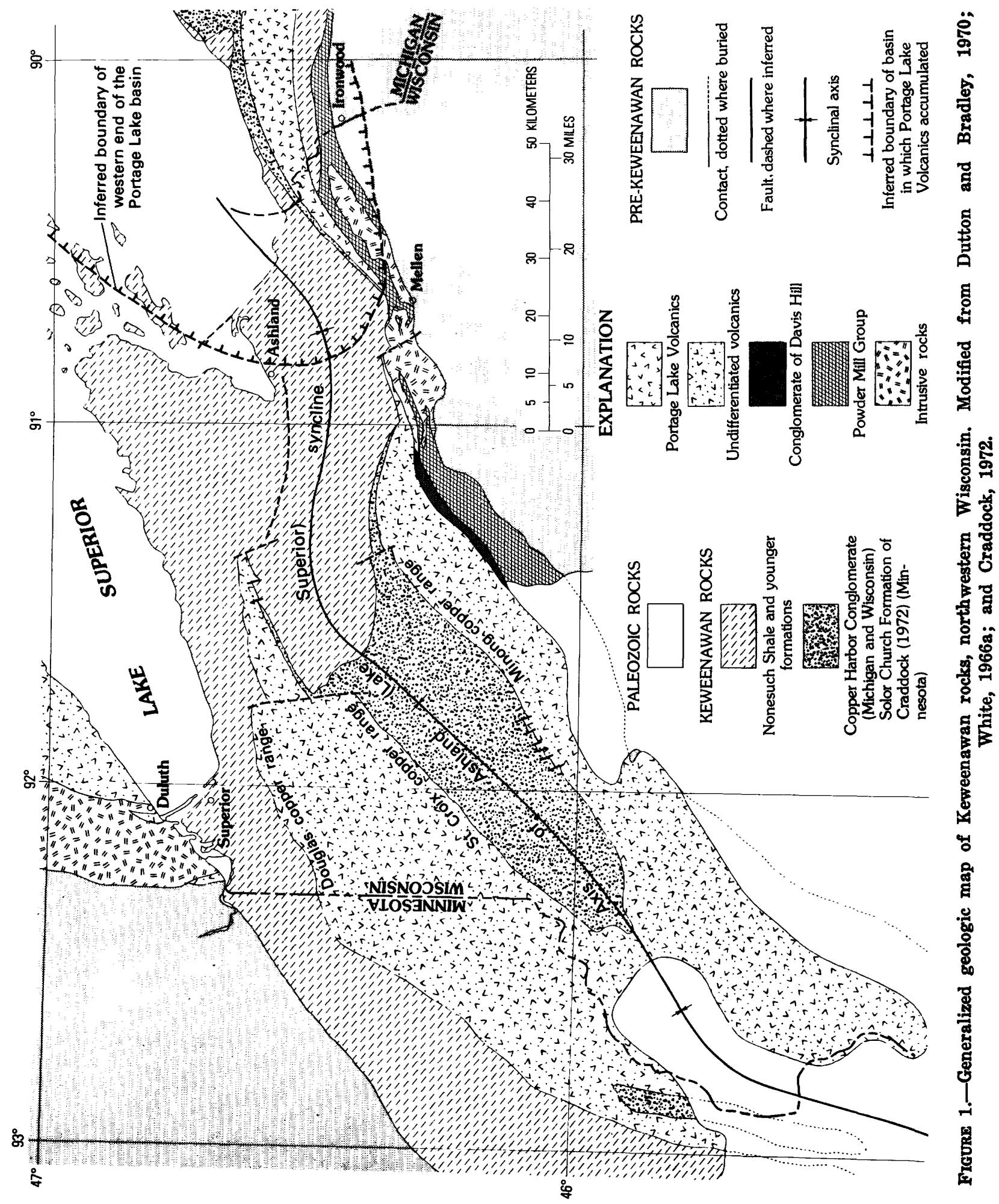


The Portage Lake Volcanics accumulated in a basin, part of the midcontinent rift of Keweenawan age, and figure 1 shows by a hachured dashed line the general outline of the western margin of this basin as reconstructed by White (1972). Termination of this basin at the pinchout of the Portage Lake Volcanics near Mellen implies that lavas of the younger volcanic formation (or formations) farther west in Wisconsin were poured out in a separate basin, and might or might not be contemporaneous with the Portage Lake Volcanics. For purposes of exploration for copper, contemporaneity with the Portage Lake Volcanics is probably less important than certain other characteristics that the younger volcanics of Wisconsin share with the Portage Lake. The following paragraphs discuss these points of similarity.

\section{GEOLOGIC FEATURES COMMON TO YOUNGER LAVAS OF MICHIGAN AND WISCONSIN}

\section{SHOWS OF NATIVE COPPER OR CHALCOCITE}

One of the simplest but also, perhaps, most encouraging of the favorable characteristics of the younger volcanic formation ( $\mathrm{s}$ ) of Wisconsin is the common presence of megascopic specks of native copper or copper sulfide. In areas underlain by the Portage Lake Volcanics in Michigan, few large roadcuts lack copper stain on one or more joint faces. Similarly, specks of native copper are a very common feature of the amygdaloidal part of individual lava flows as seen in drill core. That this is not a universal characteristic of Keweenawan flood basalts is shown by the fact that few, if any, of the numerous roadcuts in mafic lava along the coastal highway between Duluth and Grand Portage, Minn., show any copper stains (personal observation), although chemically and mineralogically the mafic lavas of Minnesota overlap those of Michigan in composition. Green (1972, p. 331-332) noted the scarcity of copper-mineral occurrences in northeastern Minnesota. The great difference in abundance of visible traces of copper is probably due to differences in amounts of metamorphism and movement of heated water through the rock (White, 1957; Green, 1972). But whatever the cause, the common presence of at least traces of megascopic copper minerals on joint faces and in amygdaloidal rocks would appear to be evidence that an environment favorable for migration of copper-an essential condition for the formation of economic deposits-was present in Michigan and not, to any notable extent, in northeastern Minnesota. The many copper prospects and recorded occurrences of copper minerals in northwestern Wisconsin (Grant, 1901 ; Dutton, 1972), on the other hand, suggest that an environment favorable for migration of copper did exist in this area.

\section{DEGREE OF METAMORPHISM}

The rocks of the Portage Lake Volcanics in Michigan have been regionally metamorphosed to grades that range from zeolite facies to lower greenschist facies. In general, metamorphic grade increases with stratigraphic distance below the top of the formation as a whole. In individual lava flows, minerals of metamorphic origin are abundant in the upper amygdaloidal portions, whereas the original igneous minerals -intermediate to calcic plagioclase, pyroxene, and even olivine-are best preserved in the massive basalt of the middle and lower parts of flows; some of this massive basalt is remarkably fresh. This contrast in metamorphism can be attributed to the greater availability of water for metamorphic reactions in the originally porous vesicular and fragmental flow tops, and to lack of water in the relatively anhydrous massive interiors of flows.

The most conspicuous minerals of metamorphic origin are those that fill amygdules and other original open spaces in flow tops. Using these secondary minerals, Stoiber and Davidson (1959), following Broderick (1929), were able to map crude metamorphic zones in the area of principal copper deposits. They found (their fig. 7) that all but two of the major copper deposits lie close to the top of a zone in which epidote and quartz are common amygdule fillings (fig. 2). Considerable overlap exists between this zone and a higher zone in which prehnite is an abundant amygdule filling-that is, rocks characterized by prehnite are found in the upper part of, and also above, the zone that has epidote-quartz fillings. All but one of the major deposits lie within the zone of overlap, and only 


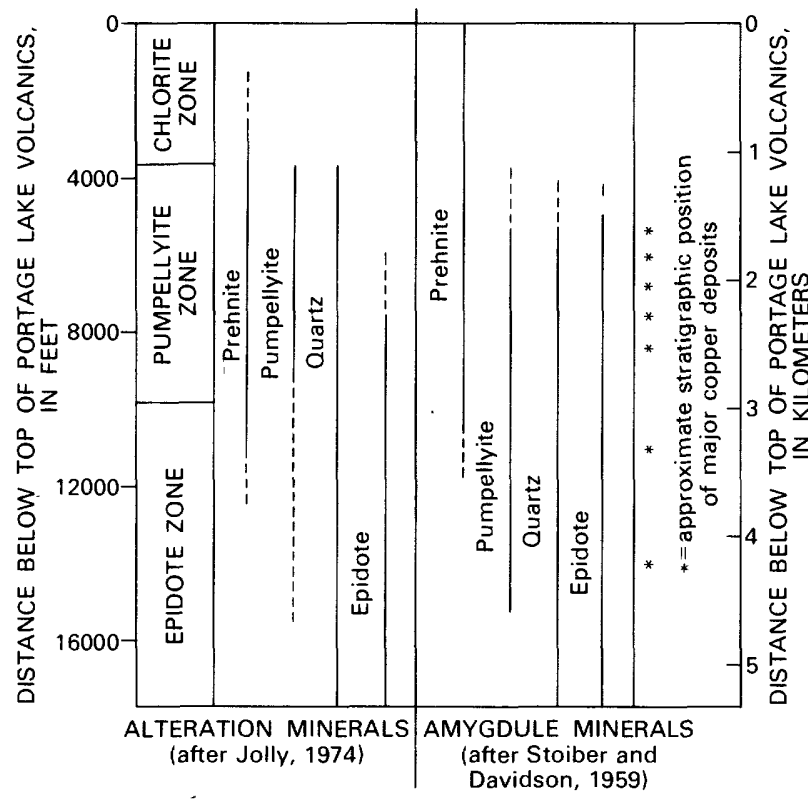

FIgURE 2.-Stratigraphic distribution of critical metamorphic minerals, Portage Lake Volcanics, Eagle Harbor section. Base of pumpellyite zone taken at top of Scales Creek Flow (Jolly, 1974, fig. 5), which is approximately $2.96 \mathrm{~km}$ (9,700 feet) stratigraphically below top of Portage Lake Volcanics.

one lies below the lower limit of prehnite, in rocks characterized by the amygdule-mineral assemblage, quartz-epidote without prehnite.

Jolly (1974) and Jolly and Smith (1972) studied the metamorphic alterations of the basaltic rock itself, rather than the amygdules, and were able to refine considerably the concept of regional metamorphic zoning. In the region occupied by the major copper deposits, they distinguish an upper laumontite (chlorite) zone, an intermediate pumpellyite zone, and a lower epidote zone (fig. 2). The epidote zone is characterized by the presence, particularly in the amygdaloidal tops of some flows, of masses of epidotized rock ranging in diameter from a few centimeters to more than a meter (epidote metadomains). Similar masses in the pumpellyite zone have pumpellyite, rather than epidote, as their dominant calcium-silicate mineral (pumpellyite metadomains). In the epidote zone, original calcic plagioclase in the flow tops is altered to albite plus epidote, and in the pumpellyite zone, calcic plagioclase is altered to albite plus pumpellyite. A transition zone between pumpellyite and epidote zones is char- acterized by both minerals. The boundary appears to lie about $1,500 \mathrm{~m}$ (5,000 feet) stratigraphically below Stoiber's upper limit of abundant epidote in amygdules, and 300-600 m (1,000-2,000 feet) above Stoiber's lower limit of prehnite in amygdules. Only two of the major copper deposits lie below Jolly's critical boundary, and all the others lie within 300$1,500 \mathrm{~m} \mathrm{(1,000-4,000} \mathrm{feet)} \mathrm{above.}$

The literature on the Keweenawan lavas of Wisconsin contains no report of a detailed regional investigation of metamorphic zoning. Grant $(1901$, p. 62), however, noted the abundance of epidote, both as amygdules and in the masses that Jolly and Smith called "metadomains"; epidote metadomains are found associated with copper occurrences in all three of Grant's "copper ranges" (the Douglas, St. Croix, and Minong copper ranges, fig. 1). Grant also reported that prehnite is a common associate of copper on the Douglas copper range, but, though observed, is less common on the other two. Prehnite is noted as a common associate of copper in a more recent report on the Weyerhauser prospect (Minong range) (H. R. Cornwall, J. J. Runner, A. A. Stromquist, and R. W. Swanson, unpub. data, 1945). These observations suggest that the rocks known to contain copper in Wisconsin lie, in general, in Jolly's epidote zone and are, therefore, of higher metamorphic grade than those that contain most of the major copper deposits in Michigan. But the presence of prehnite as a common amygdule filling suggests, additionally, that Wisconsin copper prospects lie in the upper part of the epidote zone, and perhaps not far below the lower boundary of Jolly's pumpellyite zone, in which most of the major deposits occur in Michigan.

The metamorphic grade of the rocks at existing copper prospects may, therefore, explain why the rocks contain traces rather than an abundance of copper, but the grade is not so high as to preclude the existence of neighboring areas of slightly lower metamorphic grade that might be more promising. If one believes, following Stoiber and Davidson (1959) and Jolly (1974), that there is a genetic connection between copper deposition and metamorphic grade, then a logical early step in exploration would involve an attempt to find 
areas in which the rocks belong to Jolly's pumpellyite zone, thus locating his epidotepumpellyite boundary. In Michigan, metamorphic grade decreases as stratigraphic distance increases above the base of the Portage Lake Volcanics, so areas of lower metamorphic grades should be sought where the rocks are stratigraphically higher than, or along strike from, areas where copper is associated with epidote metadomains. Such an investigation may have been carried out already, at least in reconnaissance by one or more mining companies, but, if so, the results have not been published.

\section{HOST-ROCK LITHOLOGY}

The major copper deposits of Michigan are either in flow tops characterized by an abundance of rubbly material-the "fragmental tops" of literature on the Michigan depositsor in beds of felsite conglomerate that lie between certain lava flows. Both types of host rock are present in the lavas of Wisconsin, although because of lack of drill holes-essentially the only practical way to build up complete stratigraphic sections of these rocks-we do not know whether or not fragmental tops and felsic conglomerate beds occur with the same frequency as in Michigan. The only data adequate for a comparison come from a $300 \mathrm{~m}$ (1,000 foot) drill hole (No. 18) at the Weyerhauser prospect (H.R. Cornwall, J.J. Runner, A.A. Stromquist, and R.R. Swanson, unpub. data, 1945); the core from this hole was examined by H.R. Aldrich, B.S. Butler, and T.M. Broderick in 1925. The hole cuts rocks at the very top of the lava series. In this core, fragmental tops are as numerous and thick as in many parts of the Portage Lake Volcanics. Of the 20 flow tops intersected, 12 have at least some fragmental material, compared to an average of 21 percent fragmental tops for the Portage Lake Volcanics as a whole. The median thickness of these 12 fragmental tops at the Weyerhauser prospect is $1.8 \mathrm{~m}$ (6 feet), compared to $2 \mathrm{~m}$ (6.5 feet) for flows less than $30 \mathrm{~m}$ (100 feet) thick in the Portage Lake Volcanics. The basalt of the thicker flows is generally ophitic, as are those of the Portage Lake Volcanics. All that can be said, therefore, is that in this sample of the lavas of Wiscon- sin, inadequate though it is, the lithology is similar to that of the Portage Lake Volcanics.

Individual township reports in the files of the Wisconsin Geological and Natural History Survey (1913-30) contain many references to "ophites." No quantitative comparison is possible, but the abundance of ophitic basalt is probably not vastly different from the 34 percent of ophitic basalt in the Portage Lake Volcanics (estimates of White cited in Halls, 1969, table 2).

A felsite conglomerate bed is the host rock of the largest native-copper deposit in Michigan, and other beds host smaller deposits. Similar conglomerate beds occur with the lavas in the Minong "copper range" and in the Minnesota extension of the Douglas range (Grant, 1901 , p. 9; Morey and Mudrey, 1972, p. 426427), but the thickness and abundance of such beds in the series as a whole is not known. In Michigan, conglomerate beds tend to be poorly exposed compared to the lava flows with which they are interbedded, and their number and degree of continuity is known only because of extensive drilling.

\section{PALEOHYDROLOGY OF THE COPPER DEPOSITS}

Downdip projection of the Portage Lake Volcanics on opposite sides of the Lake Superior syncline in Michigan (Keweenaw Peninsula and Isle Royale) makes it clear that along the trough of the syncline, the lavas would be at sufficient depth to be metamorphosed at least to the greenschist facies (White, 1957, 1966b, 1968; Halls, 1969). During burial metamorphism, leakage of ground water buried with the lavas from vesicles and interfragmental spaces in the flow tops would permit collapse of these openings. The water would leak toward the surface along any available channelways. This water, if saline like the deep formation waters common throughout the world, would inevitably be much enriched in copper by the metamorphic reactions (Stoiber and Davidson, 1959; Jolly, 1974), thus fulfilling the basic requirements for the ascending ore-forming fluid that deposited the native-copper deposits.

The distribution of native-copper deposits in Michigan can be explained by a hydrologic model involving updip migration of a hydro- 
thermal fluid generated by the above mechanism. The maximum flow of fluid would be expected in areas where, other things being equal, the path from the depths of the Lake Superior syncline to the surface was shortest. The best reconstruction one can make of the structure of the Lake Superior syncline suggests that rocks of the Portage Lake Volcanics now exposed at the surface are closest to the deepest part of the trough of the syncline in an area extending southwest from the main copper district (White, 1957, 1968). The area that includes all the major deposits is farther northeast than one might expect if proximity to the deepest part of the basin were the only factor involved. One or more of at least three factors may explain this apparent displacement of the area of major deposits.

\section{DEGREE OF METAMORPHISM}

The area of Portage Lake Volcanics closest to the deepest part of the basin is an area in which the rocks have been metamorphosed to the grade of Jolly's (1974) epidote zone, and are thus of higher grade than the empirical optimum for major copper deposits. Within this area of higher metamorphic grade, there are actually a number of native copper deposits (see the two areas shown as containing minor deposits in fig. 1 of White, 1968) ; but though some of these deposits produced thousands of tons of metallic copper, their grade was generally marginal or submarginal, and they accounted for little more than 1 percent of the district production of native copper. If degree of metamorphism is, indeed, a major controlling factor, there may once have been major deposits in this area, but they would have been in rocks of lower metamorphic grade (pumpellyite zone) updip from the present surface, in rocks that have now been eroded away. According to this interpretation, the minor deposits now found in the area may be the downdip roots or tails of long-vanished major deposits.

\section{PERMEABILITY ANISOTROPY}

The easiest path from a point in depth to the surface need not be directly updip if the most open channelways rake at some lower angle. In some of the major are deposits there is clear evidence of alternating zones of more and less permeable rock. These zones tend to be essentially parallel to the margin of the basin of lava accumulation, and generally rake westward in the main copper district. Westward-raking channelways would tend to produce a northeastward displacement of the center of maximum mineralization (see White, 1957, 1968).

\section{REGIONAL DISTRIBUTION OF MOST-POROUS ROCK}

The existence of a reservoir of buried water is an essential feature of the hypothesis that the copper was deposited by water buried with the lavas and squeezed from them in depth during burial metamorphism. The principal reservoir would be the interfragmental spaces of fragmental flow tops and of conglomerate beds. I have estimated (White, 1968, p. 323) that original voids made up roughly 2.5 percent of the total lava column, an estimate based on the ratio of secondary fillings to solid lava in the part of the Portage Lake Volcanics now accessible to view. This ratio may or may not be typical of parts of the formation now deeply buried. The ratio depends on the relative abundance of fragmental versus smooth-topped flows and on the number and thickness of conglomerate beds; both factors were very likely different in different parts of the area of lava accumulation. An attempt to predict the abundance of voids in the deep parts of the Lake Superior syncline requires reconstruction of the paleogeography of the area at the time the lavas accumulated.

The Keweenawan lavas of the Lake Superior region are part of a belt about $1,600 \mathrm{~km}(1,000$ miles) long and 80-160 km (50-100 miles) wide in which there is a major accumulation of mafic rocks. This belt most probably represents a continental rift of some sort. Increasing evidence also shows that the mafic rocks are the product of a number of separate episodes of magmatic activity rather than a single major event (see Green, 1972, p. 292-297 and fig. $\mathrm{V}-5$ ) and that separate basins of accumulation can be identified (White, 1972). Within an individual basin, such as that in which the Portage Lake Volcanics accumulated, the abundance both of fragmental flow tops and of 
conglomerate would probably be greater toward the margins than in the center. Many of the arguments on which this conclusion is based are necessarily speculative, because there are no good modern analogs for many of the phenomena involved.

The Keweenawan flood-basalt flows that have fragmental tops differ in important respects from the aa flows whose outpouring has been observed by man. (1) A typical aa flow has a layer of rubbly debris underlying, as well as one overlying, the massive lava in the center; the underlying layer in aa flows is formed by overriding of fragments that tumble down the leading edge of the flow as it advances with action like that of a caterpillar tread. In contrast, typically little or no fragmental material is found at the base of the Keweenawan flood basalts. (2) The fragments of aa flows are typically spinose, whereas those of the $\mathrm{Ke}$ weenawan flood basalts appear to be simply broken-up vesicular rock of the sort that caps the smooth-topped flows.

Flood basalts differ from those observed to flow from modern shield volcanoes primarily in respect to both the absolute volume of lava and the rate of extrusion. The average volume of lava in individual flood-basalt flows is about 2 orders of magnitude larger than the average volume in modern flows, and the rates of extrusion and spreading of lava are comparably greater (White, 1960; Shaw and Swanson, 1970; Swanson and others, 1975). The persistence and near-parallelism of flow tops for great distances in the Michigan copper district make it clear that the lava flows must have come to rest as nearly horizontal sheets on what was topographically a great plain, as was first suggested by Sandberg (1938).

On the assumption that fragmental flow tops are largely formed, as their appearance suggests, by crushing of ordinary smooth (pahoehoe-type) crust, one would expect to find fragmental tops primarily toward the margins of the area covered by an individual flow (fig. $3)$. Near the vent area, the crust would be carried along passively on the fluid lava beneath, and nothing would impede its forward motion. Insofar as the flow increased in width away from the vent, the crust would be stretched, and cracks would probably form parallel to the

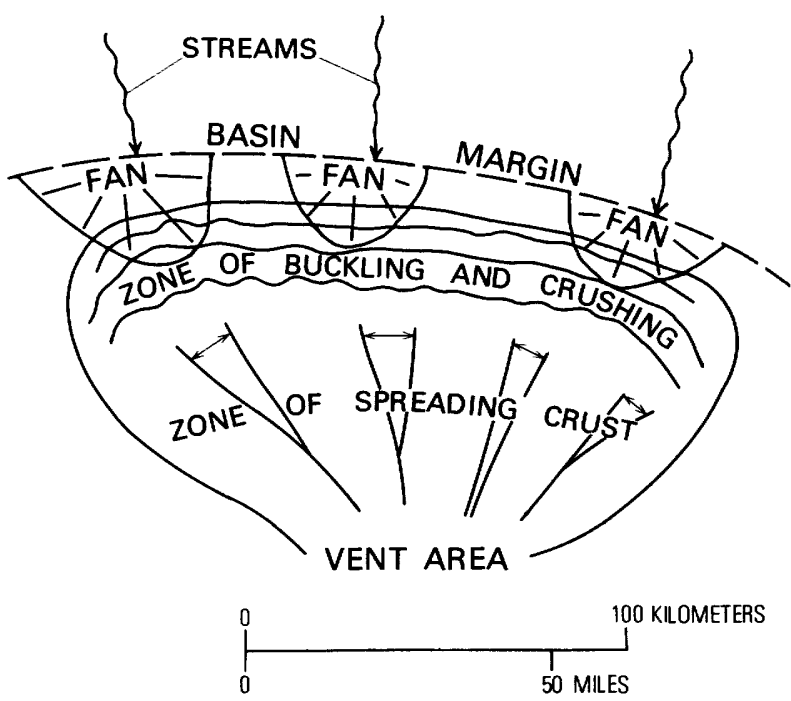

Figure 3.-Hypothetical plan of a Keweenawan floodbasalt flow. Smooth-topped lava in the zone of spreading crust is presumed to grade into fragmentaltopped lava in the zone of buckling and crushing. Conglomerate beds overlying certain flows are interpreted as alluvial fans deposited by streams flowing into the basin from the margins.

direction of flow. But toward the margins of the flow where lava was ponded against a reverse slope at the basin margin, or against a levee of its own debris, a very different situation would exist. Even after the vent had ceased its activity, lava seeking hydrostatic equilibrium would continue to flow toward the margin, the additions of fluid near the margin being accommodated by increase in the depth of the fluid-lava pool. The crust carried forward by these additions of fluid lava would, of necessity, be ground against the crust already capping the pool. For this reason, I suggest here that fragmental flow tops form primarily where forward motion of a flood-basalt sheet decreases or ceases as the fluid becomes pond$\mathrm{ed}$, and that this phenomenon is to be expected most commonly near the distal parts of individual basalt floods-the parts farthest from the vent area.

This model for the genesis of fragmental flow tops can be used to predict regional variations in the abundance of fragmental tops only if one knows the location of the vents from which the lavas came. This location in the Portage Lake Volcanics is not known with any certainty. Dikes are almost unknown within 
the areas where rocks of the formation are now exposed. Inasmuch as all these areas lie near the periphery of the basin of accumulation, the vents are presumably either outside the basin ${ }^{1}$ or deep under Lake Superior, closer to the center of the basin. Bent pipe amygdules (observations first made by Butler and Burbank, 1929 , p. 26-27, and confirmed in more recent work by the U.S. Geological Survey) indicate a more or less central source. Assuming, then, that the flows are derived from vents in the central parts of the basin, one would expect fragmental flow tops to be most common toward the margins.

The distribution of interflow conglomerates is presumably similar. Foreset beds and imbricate structure indicate that the interflow conglomerate beds of the Portage Lake Volcanics were deposited as fans by streams flowing inward from the margins of the basin (fig. 3) (White, 1957, 1960). The sedimentary rocks of the overlying Copper Harbor Conglomerate (fig. 1) are, for practical purposes, identical to those of the Portage Lake Volcanics, suggesting that they were derived from the same source terrain; these Copper Harbor sediments were also deposited by streams flowing inward from the margins of the basin (White and Wright, 1960; Hamblin, 1961; Hamblin and Horner, 1961; Wolff and Huber, 1973 (data from Isle Royale); Hubbard, 1972).

In a typical sedimentary basin, individual stratigraphic units would be expected to thicken toward the center of the basin. The situation would be entirely different, however, in a basin filled primarily with lava flows. In particular, if the lava flows are fed by fissures located in the central parts of the basin, streams flowing inward from the margins would be ponded or diverted sideways, sooner or later, against the slopes of the volcanic shields, however low, that would surround the area of the fissure eruptions. In fact, the basinward slope that would make any inflow of streams from the margin possible would presumably be due mostly to periods in which outpouring of lava did not keep pace with continued subsidence

\footnotetext{
1 The swarms of Keweenawan dikes in areas of pre-Keweenawan rocks outside the basin, once thought to be a possible source of Portage Lake flows, are now known from paleomagnetic evidence to be older, perhaps more or less contemporaneous with all or part of Hubbard's Powder Mill Group.
}

of the basin (White, 1957, 1960). During such a period of volcanic inactivity, subsidence could reverse the initial outward (toward the basin margin) slope of the most recent lava flow, at least near the basin margin, permitting streams to course out over that flow toward the center of the basin. Conglomerate beds occur at intervals of roughly 250-300 m (8001,000 feet) throughout the column of lava flows, suggesting cyclic fluctuation in the intensity of volcanic activity. Under these circumstances, the longer the interruption of volcanism, the greater the amount of subsidence before the next volcanic episode. The longest interruptions would thus be represented by the thickest conglomerate beds, which, other things being equal, would also be those that extended, as alluvial fans, farthest into the basin.

Another factor would work to the same effect. A stream pouring out over the rough permeable surface of a flow would quickly lose water to its bed and, of necessity, drop its load of gravel. The water seeping into the underlying lava would carry the sand and silt fraction of its load down with it, and gradually chink in the interstices. As this chinking process was completed up to the top of the flow at any place, subsequent loss of water to the streambed would be minimal, and the gravel deposit could be extended farther from the margin. The results of this process are clearly evident today: virtually all the interfragmental spaces in flow tops just below conglomerate beds are completely filled with fine-grained detrital material. As a result of this process, alluvial fans could extend only slowly out into the basin, and again one would expect the longest intervals of nonvolcanism to be represented by the thickest and most extensive conglomerate beds.

The total of all conglomerate beds, therefore, would include some that extend only a short way inward from the basin margin and others that extend far inward. The total amount of conglomerate in the lava column, therefore, would be greatest somewhere near the basin margin and would diminish inward. Field observations support this model. The ratio of conglomerate to lava is only about 3 percent on the Keweenaw Peninsula proper, where the Portage 
Lake Volcanics are thickest and farthest from the margin of the basin. The ratio reaches $8-10$ percent a few tens of kilometers southwest, where the formation is much thinner and represents a part of the basin closer to the original margin.

In another example, the fine-grained character and relative scarcity of interflow sediments in the North Shore Volcanic Group of Minnesota (Green, 1972, p. 301) are consistent with Green's (1972, p. 308) observation that primary features of the lava flows suggest no uniform or preferred flow direction. These are all features that one would expect if the model for the Portage Lake Volcanics is applicable and the Minnesota shoreline (where most of the observations have been made) lies close to the axis of the basin in which the North Shore Volcanic Group were accumulated.

In summary, what is known and can be inferred about the distribution of fragmental flow tops and conglomerate beds in the Portage Lake Volcanics suggests that, in general, they should be most abundant toward the margins of a lava basin, and should decrease toward the central part (fig. 4). To the extent that the primary voids in fragmental flow tops and conglomerate beds form the main reservoir from which water of metamorphic origin-the inferred ore-forming fluid for the native-copper deposits-was derived, the largest reservoirs would be expected in areas where marginal parts of the lava basin lie in the trough of the Lake Superior syncline. (The "Ashland syncline" (Dutton and Bradley, 1970, sheet 3) is a local name for the

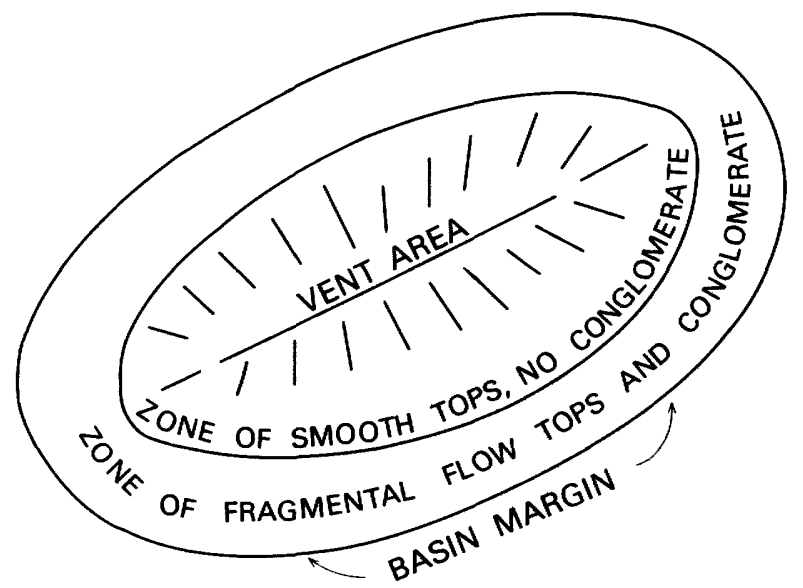

Figure 4.-Generalized model of a Keweenawan lava basin.
Wisconsin segment of the Lake Superior syncline.) This syncline is a tectonic feature involving sedimentary rocks much younger than the various volcanic formations of the Lake Superior region, and is thus demonstrably younger than the basins in which the lavas accumulated. Where the rocks in the trough of the Lake Superior syncline represent the central part of the basin in which the Portage Lake Volcanics accumulated, the amount of water driven from the trough of the syncline might be relatively small. But the axis of the syncline crosses the margin of the basin at both its ends; one of these crossings is near Ashland (see fig. 1) ; the other is deep beneath Lake Superior and cannot be located with any certainty, but probably lies somewhere northeast of the eastern end of the Keweenaw Peninsula (see map in White, 1972). Near both these crossings, the rocks in the trough of the syncline would be expected to contain relatively abundant fragmental flow tops and conglomerate beds, and thus to form important reservoirs for ore-forming solutions.

In conclusion, the speculations in this section of the paper were prompted by the need to explain why the major native-copper deposits lie farther northeast than might be expected if proximity to the deepest part of the lava basin were the principal control. In addition to the two other factors already discussed more briefly -degree of metamorphism and permeability anistropy-we arrive at another possible explanation; namely, that the rocks in the trough. of the Lake Superior syncline downdip from the major native-copper deposits are farther from the source area of the lava flows, and thus contained more fragmental lava and conglomerate and a larger reservoir of buried water than existed farther west. I have devoted a disproportionate amount of space to this third possibility in part because it has not been described previously in print, and in part because it has potential application to exploration for native copper in Wisconsin as well as in Michigan.

\section{REGIONAL STRUCTURE OF THE KEWEENAWAN LAVAS IN WISCONSIN}

\section{GENERAL STATEMEN I}

Existing knowledge of the geologic structure of the Keweenawan lavas in Wisconsin is not 
adequate to allow one to distinguish areas more and less favorable for exploration on the basis of geologic structure. The configuration of the Lake Superior (Ashland) syncline is known, and it is clear that, in the trough of this syncline, the copper-bearing lavas overlying the conglomerate of Davis Hill (fig. 1) reach depths of more than $7,500 \mathrm{~m}(25,000$ feet $) .{ }^{2}$ But the configuration of the basin or basins in which the copper-bearing lavas originally accumulated is not known, and, as has been shown in the preceding section of this paper, some knowledge of basin configuration is essential for reconstructing such paleohydrologic systems as may have produced and channeled ore-forming fluids.

Although concrete evidence for the configuration of the lava basin or basins is lacking, it may, nonetheless, be worthwhile to attempt a crude reconstruction using information that is available. The results of such an attempt may well contain gross errors, but they show, first, the kinds of data that are needed to make a better reconstruction. Second, the resulting reconstruction, right or wrong, can be used to illustrate how one might use more reliable knowledge of the structure to derive a paleohydrologic model that could, in turn, help delineate areas more and less favorable for exploration. By using this way of describing a methodology, I run some risk that a reader may take too seriously the actual results, forgetting, first, the tenuousness of the theory and, second, the inadequacy of existing geologic data. The hope is, of course, that the discussion and illustration will suggest essential elements of a proper investigation to individuals or organizations that may at some time be in a position to undertake an investigation.

\section{KINDS OF INFORMATION USEFUL FOR STRATIGRAPHIC SUBDIVISION AND CORRELATION}

As preface to the attempt at reconstruction, I shall discuss briefly the kinds of information that do exist or can be obtained for Keweenawan lava basins in general.

The stratigraphy of the Portage Lake Vol-

2 Lavas are shown extending to depths of as much as $15 \mathrm{~km}$ (10 miles) in section $J_{-} J^{\prime}$ of figure 3 in White (1966a), bnt this section is based in part on interpretation of gravity anomalies, and the volume of rock shown as "lava fiows" includes lavas below the conglomerate of Davis Hill; these lower lavas are not known to contain significant concentrations of copper, as noted above. canics is known almost flow by flow for a distance of $150 \mathrm{~km} \mathrm{(90} \mathrm{miles)} \mathrm{east} \mathrm{of} \mathrm{long.}$ $89^{\circ} 30^{\prime} \mathrm{W}$., due primarily to the enormous amount of diamond drilling that has been done in the search for copper deposits. The cost of this tool makes its use unthinkable as a means of stratigraphic mapping, but limited use is highly desirable for (1) establishing at least one standard stratigraphic section of the lavas (preferably made early rather than late in a regional survey), and (2) solving critical problems of stratigraphic correlation that cannot be resolved with data collected at the surface (presumably late in a regional survey).

In areas of good exposure, it is possible by surface geologic mapping alone to attain a very satisfactory degree of stratigraphic subdivision and correlation, as the work of Lane (1898) and Huber (1973b) on Isle Royale, and Green (1972) along the Minnesota coast has shown. Results for many areas of the Portage Lake Volcanics on the south shore of Lake Superior, on the other hand, would have been very much less satisfactory without the aid of diamond-drill data. Even less satisfactory results are to be expected for much of the Keweenawan lava accumulations of Wisconsin, particularly if, in contrast to the experience in Michigan, detailed mapping shows few, if any, individual flows or conglomerate beds that, by reason of unusual thickness or lithology, can be confidently traced for distances of many tens of kilometers.

The usefulness of outcrop mapping, particularly for stratigraphic correlations and local structure, can be enormously enhanced by magnetic surveys (see Hotchkiss and others, 1915, p. 75-136; Broderick and Hohl, in Butler and Burbank, 1929, p. 161-168; Aldrich, 1929, p. 70-73; Lamey, 1938). The references cited all describe the use of the dip needle for magnetic mapping. Far more accurate and precise results and far greater speed and convenience can be obtained today from field magnetometers now available, but the principles of interpretation are the same. The upper amygdaloidal part of a mafic lava flow is normally much less magnetic than the massive basalt of the interior of the flow. As a result, successive measurements along a traverse at right angles to the strike of dipping flows yield a jagged curve in which pairs of highs and lows tend to 
represent individual flows. One typically has little difficulty in correlating flows between the two, provided the distance between traverses is not too large, even though no two adjacent traverses would be expected to yield curves that are completely congruent. Exceptionally large highs, lows, or steps that fairly consistently mark certain flows or stratigraphic horizons can, of course, greatly strengthen intertraverse correlations.

The results of surface and airborne magnetometer surveys can be usefully combined, because the peaks and lows on an aeromagnetic profile represent groups of flows and tend to be traceable for longer distances than individual features of ground profiles.

Brief mention should also be made here of another tool for correlation, potentially very powerful, that to date has been used only to correlate major subdivisions of the Keweenawan rocks of the Lake Superior region. This is paleomagnetism (DuBois, 1962; Books, 1972). The detailed flow-by-flow study by Books of a section of the Portage Lake Volcanics on the Keweenaw Peninsula suggests that the paleomagnetic direction characteristic of individual flows and groups of flows may, in places, be sufficiently different from one another to permit boundaries to be drawn and correlations made within a lava series. Books (1972, fig. 21) presented, as an example, the paleomagnetic evidence for correiation of a specific horizon between the Keweenaw Peninsula and Isle Royale, on opposite sides of the Lake Superior syncline. This tool should ultimately provide some of the best evidence for subdivision of, and correlation from place to place within, the Keweenawan lavas of Wisconsin.

Finally existing gravity and aeromagnetic maps of the region (Dutton and Bradley, 1970, sheet 2; Ervin and Hammer, 1974) provide bi oad constraints for the regional stratig. raphy and structure.

\section{DATA AVAILABLE FOR WISCONSIN}

Most of what is known about regional geology of the Keweenawan lavas of Wisconsin is the product of two major undertakings of the Wisconsin Geological and Natural History Survey. The most useful today are (1) the report on Grant's (1901) investigation of the copper occurrences, and (2) the products of an extensive series of geologic and magnetic surveys of individual townships carried out between 1912 and 1930 for the purpose of mineral-land classification. Reports on a number of townships close to the southern border of the area of Keweenawan rocks have been published (Hotchkiss and others, 1915; Aldrich, 1929), but most of the reports, together with the field notebooks and specimens, are in the files of the Wisconsin Survey. Dutton and Bradley (1970) reviewed this material in preparing their report on the Precambrian rocks of Wisconsin.

Although the primary goal of the 1912-30 survey was to determine as expeditiously as possible the "evidence that exists as to the presence or absence of iron-bearing rocks, and as to the geologic structure of the region" (Hotchkiss and others, 1915, p. 5), some of its results can be applied to the problem of regional stratigraphic correlation within the lava series. The location of the top of the volcanic sequence is known rather precisely for much of the length of its trace, providing a useful datum for stratigraphic measurements. And the magnetic surveys produced lines of magnetic anomaly that, where numerous and parallel, can be taken to represent the trend of bedding. (Dutton and Bradley (1970) show these magnetic trend lines as well as outcrops on their sheet 1.) And, finally, if the specimen collection is complete enough, study might well provide some basis for subdividing and correlating, particularly if there should prove to be some fairly distinctive units or lithologic boundaries within the lava series. This last effort has not, to my knowledge, been undertaken with the goal of correlation in mind.

\section{HYPOTHETICAL MODEL OF A BASIN OF LAVA ACCUMULATION}

It is possible to generate, primarily from the magnetic data, an example of the kind of configuration of a lava basin that one would hope to get reliably from a detailed knowledge of the stratigraphy of the lava series. Inspection of the magnetic trend lines compiled by Dutton and Bradley (1970, sheet 1) reveals a number of places where the lines converge 
(or diverge) to a marked degree. The boundary between two areas whose trend lines converge or abut one against the other can obviously have more than one reasonable geologic explanation, such as a fault or an unconformity. Given good exposures and adequate stratigraphic knowledge, one can ordinarily discriminate between the possibilities, but at present this cannot be done for the region under discussion. Simply for the purpose of generating a model, therefore, let us assume that certain boundaries between areas of differing magnetic trend represent an unconformity. The boundaries between areas designated as units $A$ and $B$ in figure 5 were drawn to make such a separation.

The areas of unit $A$ on opposite sides of the Lake Superior (Ashland) syncline are both lenticular, and their outcrop patterns suggest a lens-shaped body of lavas overlying those of unit B. By using such information as is available on the dip of the lavas and the breadth of outcrop shown, one can derive approximate values for the thickness of the hypothetical lava sequence within unit $A$ at different points. If, further, one assumes that this lens-shaped body of lavas is elliptical in plan, the size and orientation that yield the best fit with the thickness estimates are suggested by the elliptical thickness contours (isopachs) in figure 5. All the uncertainties make it unwise to attach much value to this specific result. The orientation of the long axis, in particular, lies strongly athwart the trend of the midcontinent gravity high; the long axes of basins suggested primarily by interpretation of gravity anomalies, in contrast, tend to be subparallel to the midcontinent gravity high (see map in White, 1972). Furthermore, magnetic lines in the areas of unit $A$ (the upper group of lavas) are more commonly cut by the boundary than those of the area of unit $B$, a situation opposite from that which characterizes most unconformities. Much of the northern edge of the basin as drawn in figure 2 does, however, follow a prominent low on the aeromagnetic map and is also subparallel to a very large northeastward-sloping declivity on the Bouguer gravity map (Dutton and Bradley, 1970 , sheet 2), both of which features may be reasonably attributed to the margin of a basin of lava accumulation. As emphasized above, this attempt to define the extent of a lava basin in three dimensions was not carried out with any serious hope that presently available information is adequate for reaching a correct interpretation. It was made simply (1) to illustrate, by example, how stratigraphic information can be used to determine the geometry of individual basins of lava accumulation, (2) to show the kind of situation that better stratigraphic information might reveal, and (3) finally, to generate a hypothetical model of basin geometry that can be used to illustrate the use of such knowledge. The remainder of this section is devoted to the last-named topic.

The isopachs of figure 5 define the original shape and extent of a hypothetical basin of lava accumulation which can be designated basin $A$. The lavas of unit $B$ below it were presumably accumulated in an earlier basin or basins that will be designated as basin $B$. The eastern boundary of basin B is suggested by the doubly hachured line; this line simply connects apparent pinchouts of the lavas of basin $B$. The copper prospects in the areas described by Grant (1901) as the St. Croix and Minong copper ranges are in rocks of basin $\mathrm{A}$, and the copper prospects of the Douglas range and probably of the Chengwatana Volcanic Group of Morey and Mudrey (1972, p. 425-430) of adjoining parts of Minnesota belong to basin $B$, provided there are no additional stratigraphic complications.

\section{AREAS FAVORABLE FOR COPPER IN HYPOTHETICAL LAVA BASINS}

Experience in the Michigan native-copper district has, as described earlier, suggested three factors that may affect the regional distribution of copper deposits formed by downwarp (in the Lake Superior syncline) of these hypothetical lava basins. These factors are (1) the grade of metamorphism, (2) the orientation of primary irregularities in flow tops (White, 1957), and (3) the location of areas where, by reason of above-average proportions of conglomerate and fragmental flow tops, the lavas in the trough of the syncline would have been especially porous and therefore provided an important reservoir of buried water. Evaluation of these factors in Wiscon- 


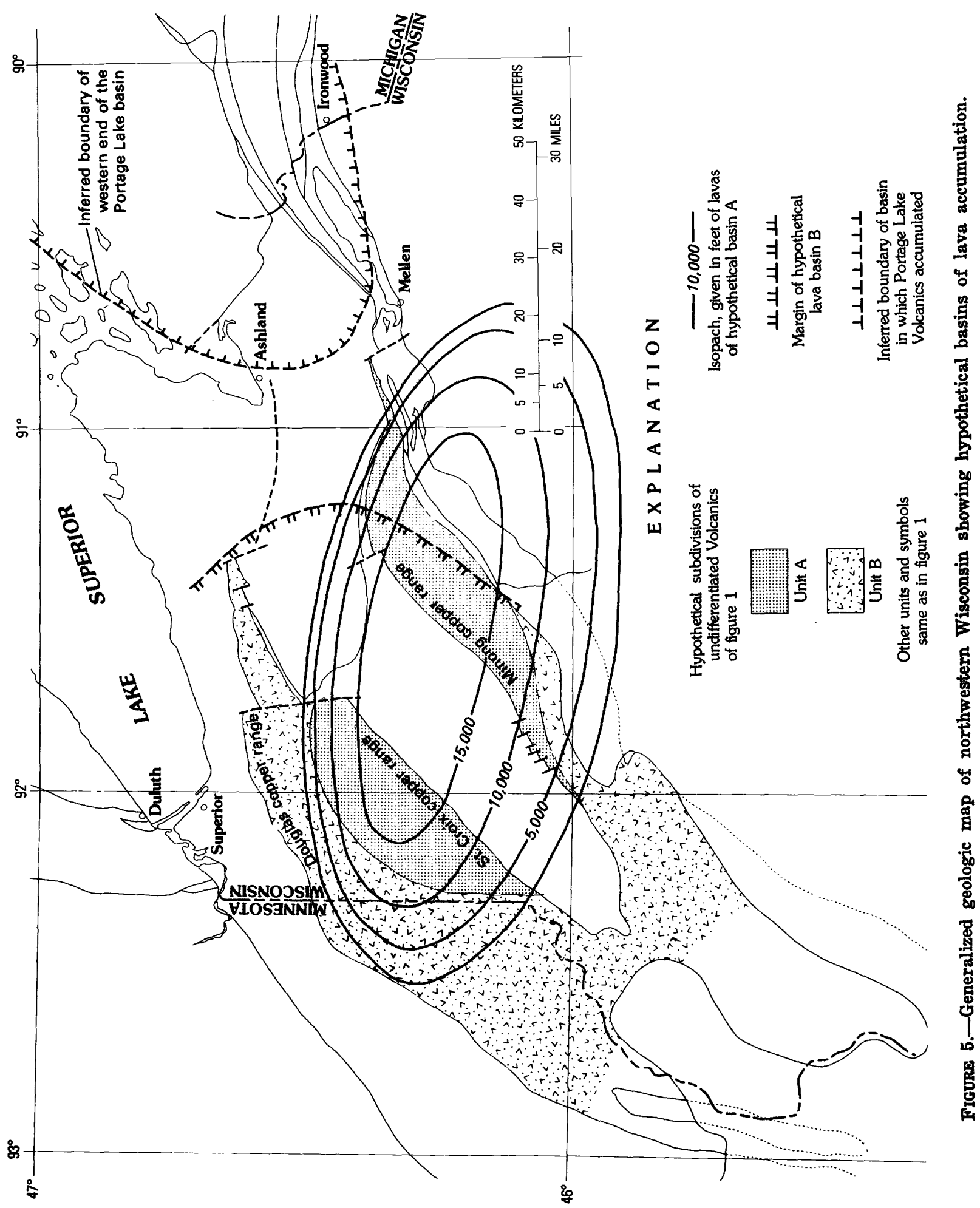


sin can be used to suggest areas most favorable for copper deposits, first in hypothetical basin $A$, and then in basin $B$.

\section{HYPOTHETICAL BASIN A}

\section{METAMORPHIC GRADE}

The metamorphic grade of the rocks at the very top of the lava series is unfavorably high in the areas described by Grant (1901) as the St. Croix and Minong copper ranges. The main copper prospects of both ranges are in the central rather than marginal parts of basin $A$ as defined by the isopachs of figure 5 . Their higher metamorphic grade therefore offers a parallel to the situation in Michigan; as noted above, the area in which rocks of the Portage Lake Volcanics at the present surface lie closest to the area of deepest downfolding is also an area in which the metamorphic grade is unfavorably high. The prospects could conceivably represent the roots of larger deposits that once existed farther updip in rocks long since eroded. Furthermore, because the metamorphic grade tends to rise with stratigraphic depth, rocks deeper in the section than those that contain the copper prospects-that is, to the northwest of those in the St. Croix range and to the southeast of those in the Minong range-are even less favorable in terms of metamorphism. The most promising areas would lie at high stratigraphic levels in basin A, along strike to the northeast and southwest of copper prospects found to be associated with epidote metadomains.

\section{PERMEABILITY ANISOTROPY}

The trend of zones of more and less permeable rock in flow tops of the Portage Lake Volcanics tends to be more or less parallel to the margin of the lava basin (White, 1957). This parallelism may be a consequence of the crumpling of flow crust along the distal margin of individual basalt floods, postulated in an earlier section of this paper. In the model for basin $A$ suggested by figure 5, the trend of permeable zones would be nearly down the present dip of bedding in all but the axial region of the basin. The trend would, therefore, be favorable for formation of copper deposits on both limbs of the Lake Superior syncline in all but a narrow zone along this axis, and this criterion is not very exclusive for the basin as drawn.

\section{REGIONAL DISTRIBUTION OF MOST-POROUS ROCK}

According to the model suggested for the Portage Lake Volcanics, the principal reservoirs of water carried to great depth by downwarping of the Lake Superior syncline would have been in areas where marginal parts of basin $\mathrm{A}$ cross the deeper parts of the Lake Superior syncline. Water driven updip from these reservoirs would have passed through the rocks in the northeastern and southwestern parts of the areas of unit $\mathrm{A}$ on both limbs of the syncline, making these rocks most favorable for the occurrence of copper according to this criterion.

\section{SUMMARY FOR HYPOTHETICAL BASIN A}

All the criteria discussed above suggest that the places most favorable for copper deposits are in the northeastern and northwestern parts of the areas of unit $A$ in figure 5 on both limbs of the Lake Superior syncline. The fact that the metamorphic grade is unfavorably high near the top of the lava series in the central part of basin A suggests that it is also likely to be unfavorable at deeper stratigraphic levels over a larger area, and perhaps over the whole basin. The most promising areas, therefore, are those underlain by rocks near the top of the lava series and within 15 to $25 \mathrm{~km}$ (10 to 15 miles) of the margin of basin $A$ as drawn in figure 5 . There are four such areas, two on the north limb of the syncline and two on the south limb. The westernmost area, which includes the southwest end of the St. Croix copper range, has at least scattered exposures, and for this reason it is doubtless the most thoroughly prospected. A large area east of the Minong copper range is underlain by rocks stratigraphically high in the lava series, and apparently has few, if any, outcrops; this is potentially the most favorable of the four areas. The other two areas are of intermediate promise.

The area east of the Minong range and, to some extent, also the one that lies across the syncline from it, would be favorable under a wide variety of assumptions about the size, shape, and orientation of basin $\mathrm{A}$. These areas are, therefore, the most promising if no further 
background studies are feasible. Discovery of epidote metadomains in either area would be discouraging.

\section{HYPOTHETICAL BASIN B}

So few inferences about the geometry of basin $B$ are possible on the basis of existing information that only some general remarks, primarily on metamorphism, seem warranted. Unlike those of basin A, the copper prospects of basin B (the Douglas copper range of Grant, 1901) are in rocks in the lower rather than upper parts of the stratigraphic column for the basin. Although the rocks that contain these prospects are characterized by epidote metadomains and are thus presumed to be unfavorable for the occurrence of major deposits, they probably do not lie very far below rocks of the pumpellyite zone (see fig. 2).

Grant (1901, p. 62-63) contrasted the abundance of prehnite in copper prospects of the Douglas copper range with the relative scarcity of prehnite in the prospects of the St. Croix range. A belt containing stratigraphically higher rocks of basin B lying south of the area of copper prospects, therefore, may well contain rocks of lower metamorphic grade. This belt is 3 or $4 \mathrm{~km}$ ( 2 or 3 miles) wide, and apparently contains virtually no outcrops. The eastern end of this belt, at least, lies beyond the margins of hypothetical basin $\mathrm{A}$ as drawn in figure 5, and thus need not contain rocks of the same or higher metamorphic grade than those of the stratigraphically higher St. Croix copper range. The eastern end of this belt without outcrops could, therefore, be much more promising than the stratigraphically lower Douglas copper range.

Taking the double hachured line as a correct representation of the eastern margin of basin $B$, this area south of the easternmost Douglas range is also relatively favorable from a paleohydrologic standpoint. Like the favorable areas of basin $\mathrm{A}$, it is fairly near the margin of a basin at a place where this margin crosses the axis of the Lake Superior syncline.

\section{PORTAGE LAKE VOLCANICS}

As shown in figure 1, lavas belonging to the Portage Lake Volcanics are exposed in a narrow belt that wedges out westward in the vicinity of Mellen. According to the tectonic criteria applied above to hypothetical basin $A$, this belt of Portage Lake Volcanics should be favorable for the occurrence of native copper, in both Wisconsin and Michigan. In terms of metamorphic grade, however, the area is less promising. Hubbard (1975) reported that all feldspars contain, or are altered to, epidote. Pumpellyite, however, does occur, at least locally, in epidote metadomains in the uppermost part of the Portage Lake Volcanics, so the top of the formation may lie fairly close to Jolly's (1974) boundary between epidote and pumpellyite zones.

\section{CONCLUSION}

Although the specific conclusions about favorable and unfavorable areas reached in the preceding exercise should not be taken very seriously because of the weakness of the underlying assumptions and, data, the principles of interpretation could be very profitably applied to a more substantial body of basic data. The nature of such a body of data is the subject of this concluding section.

As is implicit from all the foregoing, the basic information needed falls into three main categories: metamorphic grade, stratigraphy, and structure.

\section{METAMORPHIC GRADE}

Within areas containing outcrops, rocks of the epidote and pumpellyite zones are fairly easy to differentiate (Jolly and Smith, 1972). For a given outcrop this can be done by simple inspection if the altered bodies described by Jolly and Smith as "metadomains" are present. The bright pistachio green of epidote metadomains is very different from the drab grey green of pumpellyite metadomains. ${ }^{3}$ If no metadomains are present in outcrops that are critical for determining a metamorphic zone boundary, petrographic study of the altered rock between amygdules in flow tops can be used to discriminate between rocks of

\footnotetext{
s In older drill logs of the Michigan copper distriet in company files, the rock of pumpellyite metadomains is commonly called "zolsitized." Metadomains that have both epldote and pumpellyite characterize a transition zone between epidote and pumpellyite zones.
} 
the different metamorphic zones (see Jolly and Smith, 1972, p. 288-291).

The fragmentary information in the literature suggests that most, if not all, the rocks in outcrop areas belong to the epidote zone. It might be profitable, first, to study specimens of amygdaloid and altered rock in the collection of the Wisconsin Geological and Natural History Survey and then to make field examinations in critical areas to see if any rocks of the pumpellyite zone are represented in outcrops. They are to be expected high rather than low, stratigraphically, within any given lava basin. And if experience in Michigan is a reliable guide, a metamorphic-zone boundary is not likely to cut across stratigraphy at a high angle on a regional scale; the highest gradient observed in Michigan is about $40 \mathrm{~m} / \mathrm{km}(1,000$ feet/5 miles). For example, if the rocks at the very top of the lava series belong to the epidote zone at point $X$, rocks stratigraphically $600 \mathrm{~m}$ (2,000 feet) or so below the horizon of $\mathrm{X}$ can be safely assumed to be in the epidote zone for at least $8 \mathrm{~km}$ (5 miles) along strike from $X$.

These principles are of some help in the vicinity of outcrop areas, but there is probably no simple way, short of diamond drilling, to determine metamorphic grade in the larger areas of northern Wisconsin that are devoid of outcrops. Needless to say, if drilling is done in such areas for any other reason, an important extra dividend may be critical evidence on metamorphic zoning.

\section{STRATIGRAPHY}

For the purpose of determining the geometry of a basin of lava accumulation, it is not necessary to have as much stratigraphic information as is available, primarily from drill records, for the Michigan copper district (see Butler and Burbank, 1929, pl. 15). A desirable level of stratigraphic subdivision and correlation is best illustrated perhaps by Huber's (1973b) geologic map of Isle Royale National Park. The important feature of this map is that four lava flows were traced from one end of the island to the other, and a number of other units for more than $15 \mathrm{~km}$ (10 miles), providing a solid network of stratigraphic datum planes. By 'combining measurements of dip and breadth of outcrop, Huber (1973a, fig. 23) was able to prepare a longitudinal stratigraphic section for the whole island that provides important information about the north flank of the basin in which lavas of the Portage Lake Volcanics accumulated. Individual flows are farthest apart in the middle of the island and tend to converge toward the ends of the island. This suggests that the ends of the island are closer to the margins of the lava basin than the middle or, in other words, that the exposures on the island lie along chords bounding a segment of arcuate basin margin, convex toward the north.

In northern Wisconsin, scarcity or absence of outcrops in many, perhaps most, areas makes it impossible to attain this degree of stratigraphic subdivision from outcrops alone. If, however, a few horizons can be reliably traced across the areas that do contain outcrops by some combination of lithologic and magnetic mapping (Grant's map (1901, pl. 13) of the Minong range suggests that this is feasible), it is not unreasonable to expect that correlations can be made across large areas devoid of exposures. With luck, one might be able to make strictly lithologic correlations of individual flows or flow sequences in some areas. Correlation of a substantial fraction of the Portage Lake Volcanics between Isle Royale and Keweenaw Peninsula across a gap of $80 \mathrm{~km}$ (50 miles) (Huber, 1973a, p. C25C27) shows that long-distance lithologic correlations are possible.

In the absence of reliable lithologic correlations, aeromagnetic lines, reinforced by surface magnetic work in areas of ambiguity, can provide a basis for extrapolating stratigraphic boundaries for long distances. For some areas, the earlier magnetic work with dip-needle showed large numbers of lines of magnetic anomaly that could be followed for kilometers (see Dutton and Bradley, 1970, sheet 1). Where such lines are parallel and fairly straight, they can be accepted today as tools for correlation. Over much of the area underlain by lavas, however, the mapped lines are short and of irregular strike, or even nonexistent. Far more satisfactory results probably can be obtained by using the more sensitive field magnetometers now available. For the 
purposes envisaged here, to repeat all the 1913-30 traverses using modern magnetometers would not be necessary or desirable. It would be far more efficient to follow a few distinctive anomalies by short traverses, at right angles to the strike, making these traverses at far closer intervals than the half-mile intervals between traverses of the earlier surveys. Traverses $150 \mathrm{~m}$ ( 500 feet) apart have proved very satisfactory for geologic mapping of lavas in Michigan, but there will always be some places where ambiguities, such as those due to faults, can be resolved only by closer spacing. The results of earlier dip-needle surveys could be very helpful in suggesting anomalies or groups of anomalies that have sufficiently distinctive characteristics to make them easy to follow along strike.

As noted earlier, paleomagnetic measurements might provide a particularly useful tool for reliable long-distance correlation across covered areas. A basic requirement is the existence of one or more horizons that can be more or less uniquely identified by the paleomagnetic directions in a single flow or in two or more contiguous flows. To find such a horizon would initially require measuring the paleomagnetism of a large number of flows in as nearly complete a sequence of flows as one or more of the better outcrop areas afford (see, for example, Books, 1972, figs. 19 and 20). Once a useful horizon (or horizons) is found, fewer measurements should be needed to firmly establish correlation with the rocks in another area, assuming a rough correlation can be made by other means.

\section{STRUCTURE}

The structural measurement most necessary for the purpose envisaged here is the dip of bedding, inasmuch as the strike is manifest from the results of the various kinds of mapping described. If interflow sandstone or shale beds can be found, there is little problem. The dip of lava flows, on the other hand, may be difficult to obtain, particularly in exposures with small relief, because the boundaries between flows tend to be poorly exposed. Even where exposures are good, flow contacts may be sufficiently irregular to rule out a unique dip reading. A single measurement on a lone ex- posure is probably worth very little. A large number of readings made over a relatively limited area, on the other hand, should generally make possible an estimation of the dip within $5^{\circ}$ or so. For many areas, an improvement on the estimates that already exist in the townships' reports of the Wisconsin Geological and Natural History Survey may not be possible. The matter of dip is mentioned here only because anyone doing field work for any of the purposes described above should be constantly aware of the need to record every available clue to dip.

\section{REFERENCES}

Aldrich, H. R., 1929, The geology of the Gogebic Iron Range of Wisconsin: Wisconsin Geol. and Nat. History Survey Bull. 71, 279 p.

Books, K. G., 1972, Paleomagnetism of some Lake Superior Keweenawan rocks: U.S. Geol. Survey Prof. Paper 760, 42 p.

Broderick, T. M., 1929, Zoning in the Michigan copper deposits and its significance: Econ. Geology, v. 24, no. 2, p. 149-162, 311-326.

Butler, B. S., and Burbank, W. S., 1929, The copper deposits of Michigan: U.S. Geol. Survey Prof. Paper 144, 238 p.

Craddock, Campbell, 1972, Keweenawan geology of east-central and southeastern Minnesota, in Sims, P. K., and Morey, G. B., eds., Geology of Minnesota: St. Paul, Minnesota Geol. Survey, p. 416-424.

DuBois, P. M., 1962, Paleomagnetism and correlation of Keweenawan rocks: Canada Geol. Survey Bull. $71,75 \mathrm{p}$.

Dutton, C. E., 1972, Sampling of copper-bearing Keweenawan rocks of northwestern Wisconsin: U.S. Geol. Survey open-file rept., 19 p.

Dutton, C. E., and Bradley, R. E., 1970, Lithologic, geophysical, and mineral commodity maps of Precambrian rocks in Wisconsin: U.S. Geol. Survey Misc. Geol. Inv. Map I-631.

Ervin, C. P., and Hammer, Sigmund, compilers, 1974, Bouguer anomaly gravity map of Wisconsin: Madison, Wisconsin Geol. and Nat. History Survey, 2 sheets, $1: 500,000$.

Grant, U. S., 1901, Preliminary report on the copperbearing rocks of Douglas County, Wisconsin: Wisconsin Geol. and Nat. History Survey Bull, 6, 83 p.

Green, J. C., 1972, North Shore Volcanic Group, in Sims, P. K., and Morey, G. B., eds., Geology of Minnesota: St. Paul, Minnesota Geol. Survey, p. 294-332.

Halls, H. C., 1969, Compressional wave velocities of Keweenawan rock specimens from the Lake Superior region: Canadian Jour. Earth Sci., v. 6, no. 4 , pt. 1 , p. 555-568. 
Hamblin, W. K., 1961, Paleogeographic evolution of the Lake Superior region from Late Keweenawan to Late Cambrian time: Geol. Soc. America Bull., v. 72 , no. 1 , p. 1-18.

Hamblin, W. K., and Horner, W. J., 1961, Sources of the Keweenawan conglomerates of northern Michigan: Jour. Geology, v. 69, no. 6, p. 204-211.

Hotchkiss, W. O., and others, 1915, Mineral land classification showing indications of iron formation [Wisconsin]: Wisconsin Geol. and Nat. History Survey Bull. 44, 367 p.

Hubbard, H. A., 1972, Source of pebbles of volcanic rocks in the middle and upper Keweenawan conglomerates of northern Michigan: Jour. Geology, v. 80 , no. 5 , p. $627-629$.

1975, Lower Keweenawan volcanic rocks of Michigan and Wisconsin: U.S. Geol. Survey Jour. Research, v. 3, no. 5, p. 529-541.

Huber, N. K., 1973a, The Portage Lake Volcanics (middle Keweenawan) on Isle Royale, Michigan: U.S. Geol. Survey Prof. Paper 754-C, 32 p. -1973b, Geologic map of Isle Royale National Park, Keweenaw County, Michigan: U.S. Geol. Survey Misc. Geol. Inv. Map I-796.

Jolly, W. T., 1974, Behavior of $\mathrm{Cu}, \mathrm{Zn}$, and $\mathrm{Ni}$ during prehnite-pumpellyite rank metamorphism of the Keweenawan basalts, northern Michigan: Econ. Geology, v. 69, no. 7, p. 1118-1125.

Jolly, W. T., and Smith, R. E., 1972, Degradation and metamorphic differentiation of the Keweenawan tholeiitic lavas of northern Michigan, U.S.A.: Jour. Petrology, v. 13, no. 2, p. 273-309.

Lamey, C. A., 1938, A dip-needle survey of the ToivolaChallenge mine area, Michigan: Econ. Geology, v. 33, p. 635-646.

Lane, A. C., 1898, Geological report on Isle Royale, Michigan: Michigan Geol. Survey, v. 6, pt. 1, $281 \mathrm{p}$.

Morey, G. B., and Mudrey, M. G., Jr., 1972, Keweenawan volcanic rocks in east-central Minnesota, in Sims, P. K., and Morey, G. B., eds., Geology of Minnesota: St. Paul, Minnesota Geol. Survey, p. $425-430$.

Sandberg, A. E., 1938, Section across Keweenawan lavas at Duluth, Minnesota: Geol. Soc. America Bull. v. 49 , no. 5, p. $795-830$.
Shaw, H. R., and Swanson, D. A., 1970, Eruption and flow rates of flood basalts, in Gilmour, E. H., and Stradling, Dale, eds., Proc. Second Columbia River Basalt Symposium: Cheney, Eastern Washington State Coll. Press, p. 271-299.

Stoiber, R. E., and Davidson, E. S., 1959, Amygdule mineral zoning in the Portage Lake Lava Series, Michigan copper district: Econ. Geology, v. 54, nos. 7, 8, p. 1250-1277, 1444-1460.

Swanson, D. A., Wright, T. L., and Helz, R. T., 1975, Linear vent systems and estimated rates of magma production and eruption for the Yakima Basalt on the Columbia Plateau: Am. Jour. Sci., v. 275, no. 8, p. 877-905.

White, W. S., 1957, Regional structural setting of the Michigan native-copper district, in Snelgrove, A. K., ed., Geological exploration-Institute on Lake Superior Geology: Houghton, Michigan Coll. Mining and Technology Press, p. 3-16.

1960, The Keweenawan lavas of Lake Superior, an example of flood basalts: Am. Jour. Sci., v. 258A (Bradley Volume), p. 367-374.

1966a, Tectonics of the Keweenawan basin, western Lake Superior region: U.S. Geol. Survey Prof. Paper 524-E, 23 p.

1966b, Geologic evidence for crustal structure in the western Lake Superior basin, in The earth beneath the continents-a volume of geophysical studies in honor of Merle A. Tuve: Am. Geophys. Union Geophys. Mon. 10 (Natl. Acad. Sci.-Natl. Research Council Pub. 1467), p. 28-41.

1968, The native-copper deposits of northern Michigan, in Ridge, J. D., ed., Ore deposits of the United States, 1933-1967, v. 1: New York, Am. Inst. Mining, Metall., and Petroleum Engineers, p. 303-326.

1972, Keweenawan flood basalts and continental rifting: Geol. Soc. America Abs. with Programs, 1972 , v. 4, no. 7, p. 732-734.

White, W. S., and Wright, J. C., 1960, Lithofacies of the Copper Harbor Conglomerate, northern Michigan, in Geological Survey research 1960: U.S. Geol. Survey Prof. Paper 400-B, p. B5-B8.

Wolff, R. G., and Huber, N. K., 1973, The Copper Harbor Conglomerate (middle Keweenawan) on Isle Royale, Michigan, and its regional implications: U.S. Geol. Survey Prof. Paper 754-B, 15 p. 
$-$ 